\title{
The polar flagellum mediates Azospirillum brasilense adsorption to wheat roots
}

\author{
Chris L. Croes, Sara Moens, Els van Bastelaere, Jos Vanderleyden \\ and Kris W. MiCHIELS* \\ F. A. Janssens Laboratory of Genetics, Katholieke Universiteit Leuven, W. De Croylaan 42, B-300I Heverlee, Belgium
}

(Received I December 1992; revised 18 February 1993: accepted 17 March 1993)

\begin{abstract}
Azospirillum brasilense in a motile Gram-negative bacterium that can adapt its flagellation to different environments. Cells growing in a liquid culture possess only a single polar flagellum; growth on a solid surface additionally induces multiple lateral flagella. The polar flagellum is primarily used for swimming, i.e. locomotion of the bacterium in a liquid environment, whereas the lateral flagella allow the bacteria to swarm over a solid surface. We have previously described a completely non-motile $A$. brasilense mutant (Sp7 p90D084), and shown that this mutant has a drastically reduced adsorption capacity to wheat roots. In the present work, we present several lines of evidence demonstrating that adsorption to wheat roots is mediated by the polar flagellum of $A$. brasilense. First, the non-adsorbing mutant $\mathrm{Sp} 7 \mathrm{p} 90 \mathrm{D} 084$ forms no polar and no lateral flagella, but is otherwise undistinguishable from wild-type $\boldsymbol{A}$. brasilense. Second, disintegration of the flagella by heat or acid eliminates adsorption. Third, using a polyclonal antiserum against the polar flagellum filament protein (Fla1), we have isolated out of a collection of $3000 \mathrm{Tn} 5$-B30-induced mutants, three additional and genetically different nonflagellate mutants. Like Sp7 p90D084, these mutants show a severely reduced adsorption capacity to wheat roots. Finally, purified polar flagella bind to wheat roots in vitro.
\end{abstract}

\section{Introduction}

Azospirillum brasilense belongs to a group of soil bacteria often referred to as Plant Growth Promoting Rhizobacteria or PGPR, because they can stimulate plant growth either directly, or indirectly by suppression of plant pathogens. In view of their potential use as biofertilization or biocontrol agents, these bacteria have recently become the focus of intensive research efforts (Davison, 1988; Lugtenberg et al., 1991; Michiels et al., 1989). Regardless of their mode of action, PGPR depend on efficient plant root colonization to stimulate plant growth. Several bacterial properties are believed to contribute to this colonization capacity, such as chemotaxis towards root exudates, metabolism of root exudate components, suppression of competing micro-organisms, and, most importantly, the ability to bind to the plant root surface.

Attachment of $A$. brasilense to a large variety of plant roots, to suspended plant cells, and to inert surfaces has been reported (e.g. Umali-Garcia et al., 1980; Jain \& Patriquin, 1984; Murty \& Ladha, 1987; Bashan \&

*Author for correspondence. Tel. 16220921 ; fax 16200720 ; email KIAAA31@BLEKUL21.
Levanony, 1988; Eyers et al., 1988; Gafny et al., 1986). However, only a few studies give information on the attachment mechanism and on the nature of the bacterial cell surface structures involved. A $100 \mathrm{kDa}$ protein that agglutinates red blood cells was suggested to be involved in adsorption, because upon EDTA extraction of the protein from the bacteria, these lost their adsorption capacity (Madi \& Henis, 1989). This protein was not further characterized however, and was not shown directly to bind to wheat roots.

In a previous study, we have shown that attachment of A. brasilense to wheat roots proceeds in two steps (Michiels et al., 1991). First, bacteria adsorb rapidly and reversibly on the root surface. Several hours later, they become irreversibly anchored on the adsorption site. Anchoring is probably mediated by a bacterial poly. saccharide that binds calcofluor, a dye specific for $\beta-1,3$ and $\beta-1,4$ linked polysaccharides, since mutants that did not react with the dye (Michiels et al., 1990) were deficient in anchoring (Michiels et al., 1991). The adsorption step, on the other hand, could be eliminated by protease treatment of the bacteria, suggesting the involvement of a cell-surface component of a protein nature (Bashan \& Levanony, 1988; Michiels et al., 1991). We have described an $A$. brasilense mutant that is 
completely non-motile (non-swimming and non-swarming) and defective in adsorption (Croes et al., 1991). This suggested a role for the A. brasilense polar and/or lateral flagella in wheat root adsorption. Two additional observations support the involvement of the polar flagellum. First, $A$. brasilense adsorbs to various surfaces in a polar fashion, and adsorbed bacteria can often be seen rotating around their longitudinal axis (Patriquin, 1981; Umali-Garcia et al., 1980; Patriquin et al., 1983; our laboratory, unpublished observations). Second, we found no difference in adsorption capacity between bacteria grown on a solid (having both a polar and lateral flagella) or in a liquid medium (having only the polar flagellum) (Tarrand et al., 1978), and have always used the latter in our adsorption experiments (Michiels et al., 1991). In the present work, we present several independent lines of evidence for the role of the $A$. brasilense polar flagellum as a wheat root adhesin.

\section{Methods}

Bacterial strains and culture conditions. The strains used in this study are listed in Table 1. They were grown at $30^{\circ} \mathrm{C}$ on Luria-Bertani medium (LB) (Sambrook et al., 1989) supplemented with $2.5 \mathrm{~mm}-\mathrm{CaCl}_{2}$ and $2.5 \mathrm{~mm}-\mathrm{MgSO}_{4}$. Defined medium for growth tests of Azospirillim brasilense was $\mathrm{AB}$ minimal medium (MMAB) (Vanstockem et al., 1987). Antibiotics were added at the following concentrations: kanamycin, $25 \mu \mathrm{g} \mathrm{ml}^{-1}$; tetracycline, $10 \mu \mathrm{g} \mathrm{ml}^{-1}$.

Two-dimensional polyacrylamide gel electrophoresis (2-D PAGE) of bacterial proteins. Bacterial outer membrane proteins were isolated by a modification of the method of Hurlbert \& Gross (1983) as follows. Cells from a $250 \mathrm{ml}$ overnight culture in supplemented LB were collected by centrifugation ( 6000 r.p.m., $20 \mathrm{~min}$ ), and resuspended in $5 \mathrm{ml}$ water per $\mathrm{g}$ of wet cells. RNAase $\left[100 \mathrm{U}\left(\mathrm{g} \mathrm{cells}^{-1}\right]\right.$ and DNAase $\left.(100 \mathrm{U} \text { (g cells })^{-1}\right]$ were added, the suspension was chilled on ice for $15 \mathrm{~min}$, passed twice through a French Press $\left(2 \times 10^{4} \mathrm{p}\right.$.s.i.; about $138 \mathrm{MPa}$ ) with prechilled cylinder, and kept on ice. Residual cells were removed by centrifugation ( 12000 r.p.m., $10 \mathrm{~min}$ ), and the supernatant was centrifuged $\left(20000\right.$ r.p.m., $\left.30 \mathrm{~min}, 4^{\circ} \mathrm{C}\right)$. The pelleted membranes were resuspended in $0.5 \%$ Sarkosyl, incubated for $30 \mathrm{~min}$ at $28^{\circ} \mathrm{C}$, and collected again by centrifugation (20000 r.p.m., $\left.30 \mathrm{~min}, 4^{\circ} \mathrm{C}\right)$. The membranes were then resuspended in phosphate-buffered saline (PBS)

Table 1. Azospirillum brasilense strains used in this study

\begin{tabular}{|c|c|c|}
\hline Strain & Relevant properties* & Reference \\
\hline $\mathrm{Sp} 7$ & Wild-type strain; ATCC 29145 & $\begin{array}{l}\text { Tarrand et al. } \\
\text { (1978) }\end{array}$ \\
\hline Sp7 p90D084 & $\begin{array}{l}\text { Sp7 derivative carrying } \sim 13 \mathrm{~kb} \\
\text { deletion in } 90 \mathrm{MDa} \text { plasmid; } \\
\mathrm{Ads}^{-} \mathrm{Flal}^{-}\end{array}$ & $\begin{array}{l}\text { Croes et al. } \\
\quad(1991)\end{array}$ \\
\hline Sp7 XB7 & Tn5-B30 mutant; Fla1 ${ }^{-}$ & This work \\
\hline Sp7 XIIIE8 & Tn5-B30 mutant: Fla $1^{-}$ & This work \\
\hline Sp7 XVIIIB8 & Tn5-B30 mutant; Fla ${ }^{-}$ & This work \\
\hline
\end{tabular}

* Ads ${ }^{-}$, adsorption-deficient; Fla1 ${ }^{-}$, lacking the polar flagellum filament protein.
(Harlow \& Lane, 1988), collected again (20000 r.p.m., $30 \mathrm{~min}, 5^{\circ} \mathrm{C}$ ), and finally resuspended in $5 \mathrm{ml}$ PBS. Proteins were extracted from the outer membranes with phenol, and prepared for and subjected to 2-D PAGE as described previously (De Mot \& Vanderleyden, 1989). Total bacterial protein preparations were made as described (De Mot \& Vanderleyden, 1989). Electrophoretic separations were by isoelectric focusing in the first dimension, and SDS-PAGE in the second dimension. Gels were stained with Coomassie blue.

DNA hybridization. Total bacterial DNA was extracted, digested with the restriction endonucleases EcoRI and HindIII, electrophoresed, and blotted on Hybond $\mathrm{N}$ membranes (Amersham), using standard techniques (Sambrook et al., 1989). DNA from the Tn5-B30 delivery plasmid (Simon et al., 1989) was prepared by alkaline lysis (Sambrook et al., 1989), and labelled with digoxigenin-dUTP using a random primed labelling kit (Boehringer Mannheim). Hybridization was carried out at $65^{\circ} \mathrm{C}$ (Sambrook et al., 1989), and signals were detected using a chemiluminescent detection kit (Boehringer Mannheim).

Isolation of polar and lateral fiagella. We adopted the procedure described by De Pamphilis \& Adler (1971) with some modifications. Portions $(1 \mathrm{ml})$ of a fresh $A$. brasilense culture were spread on fifty $10 \times 10-\mathrm{cm}$-square Petri dishes containing supplemented LB solidified with $1.5 \%(\mathrm{w} / \mathrm{v})$ agar. After $48 \mathrm{~h}$ incubation at $30^{\circ} \mathrm{C}$ in a humid atmosphere, cells were collected in $5 \mathrm{ml} 10 \mathrm{~mm}-\mathrm{Tris} / \mathrm{HCl}(\mathrm{pH} 8.0)$ per plate. The bacteria were pelleted by centrifugation ( 4000 r.p.m., $15 \mathrm{~min}$ ) and resuspended in $100 \mathrm{ml}$ of the same buffer. This suspension was mixed for $40 \mathrm{~s}$ at maximum speed in a Waring Blender to break the flagella. The bacteria and bacterial cell debris were removed from the mixed cell suspension by centrifugation for $15 \mathrm{~min}$ at 12000 r.p.m. From the supernatant liquid, flagella were pelleted by ultracentrifugation for $90 \mathrm{~min}$ at 22000 r.p.m., and resuspended in $1 \mathrm{ml}$ of sterile water. This suspension was called the crude flagellar suspension. For further purification and separation of polar and lateral flagella, $13.4 \mathrm{~g}$ dried $\mathrm{CsCl}$ was added and the volume of the suspension was adjusted to $30 \mathrm{ml}$ with $10 \mathrm{~mm}-\mathrm{Tris} / \mathrm{HCl}(\mathrm{pH} 8.0)$. A density gradient was then established by spinning the samples for $60 \mathrm{~h}$ at $22000 \mathrm{r}$.p.m. in a Beckmann SW28 rotor. Two opalescent bands were obtained and carefully removed from the gradient with a pasteur pipette, dialysed against water, lyophilized, and resuspended in $500 \mu$ water. The material from each band and the crude flagellar suspension were inspected by transmission electron microscopy and subjected to SDSPAGE. The crude flagellar suspension contained a mixture of thick and thin flagella, being the polar and lateral flagella respectively (Tarrand et al., 1978), that was composed of two major proteins of $100 \mathrm{kDa}$ and $45 \mathrm{kDa}$. The opalescent band with the highest density contained only thick flagella and yielded the $100 \mathrm{kDa}$ protein upon SDS-PAGE. The other band corresponded to the lateral flagella and the $45 \mathrm{kDa}$ protein. These results will be reported elsewhere. As judged by SDS-PAGE with Coomassie blue staining, the $\mathrm{CsCl}$ purified flagella were $>95 \%$ pure (see Fig. $4 a$ ).

Preparation of fagella-specific antisera. Rabbits were immunized with purified preparations of polar and lateral flagella (Harlow \& Lane, 1988). Optimal working concentration and specificity of each antiserum were determined by Western immunoblotting using crude flagellar extracts. The antiserum against the polar flagellum (AS-Flal), used at a 1:50000 dilution, reacted specifically with the $100 \mathrm{kDa}$ polar flagellum flagellin (Fla1). AS-Flal did not react with flagellar or total protein extracts from the mutants lacking polar flagella. The antiserum induced with the lateral flagella (AS-Fla2) was used at the same concentration, and reacted with the $45 \mathrm{kDa}$ lateral flagella flagellin (Fla2), but also with two other components present in the extract which do not stain with Coomassie blue (probably lipopolysaccharides, see Results). However, since it did not cross-react with Flal (see Fig. 4), AS-Fla2 was considered to be useful for this study. 
Quantification of bacterial adsorption to wheat roots. The adsorption assay used in this work has been described in detail elsewhere (Michicls et al., 1991). Briefly, five excised wheat roots are shaken for $2 \mathrm{~h}$ at $30^{\circ} \mathrm{C}$ in five separate $5 \mathrm{ml}$ suspensions each containing about $10^{8}$ radiolabelled $A$. brasilense cells. The radioactivity remaining on each root after washing is expressed as a percentage of the total amount of radioactivity added to the root, and the mean of the five values is called the percentage adsorption.

Isolation of A. brasilense Tn5-B30 mutants defective in the production of the polar flagellum flagellin (Flal). Random mutagenesis in $A$. brasilense $\mathrm{Sp} 7$ was performed with transposon Tn5-B30 (Simon et al., 1989) as described carlier for Tn5 (Vanstockem et al., 1987). Approximately 3000 mutants were grown overnight individually in PVC multiwell plates, and the optical density $\left(\mathrm{OD}_{600}\right)$ was recorded with an automatic reader. Plates were emptied, washed twice with PBS (Harlow \& Lane, 1988), and incubated consecutively for 2-h periods at $37^{\circ} \mathrm{C}$ with bovine serum albumin [BSA, $3 \%(\mathrm{w} / \mathrm{v})$ in PBS], AS-Flal antiserum (1:50000 in PBS), and alkaline phosphatase-conjugated goat-anti-rabbit antiserum $(1: 3000$, Bio-Rad). After each incubation, plates were washed twice with PBS. After the last wash, plates were washed three times with Tris-buffered saline (TBS) (Harlow \& Lane, 1988), and twice with $10 \mathrm{~mm}$-diethanolamine, $0.5 \mathrm{~mm}-\mathrm{MgCl}_{2} . p$ Nitrophenyl phosphate $(0.1 \%$ in $10 \mathrm{~mm}$-diethanolamine, $0.5 \mathrm{~mm}$ $\mathrm{MgCl}_{2}$ ) was added as a substrate for alkaline phosphatase. When the colour had developed well, reactions were stopped with 0.1 M-EDTA, and the $\mathrm{OD}_{410}$ was measured with an automatic reader. For each mutant, this value was expressed relative to the culture cell density as $\mathrm{OD}_{410} / \mathrm{OD}_{600}(A)$ and compared with the values (mean of five replicates) similarly obtained for the wild-type $\mathrm{Sp} 7(B)$, and the nonflagellate mutant Sp7 p90D084 $(C)$. When $A-C<0-3(\mathrm{~B}-\mathrm{C})$, the absence of a polar flagellum in these bacteria was further tested by three criteria: (1) the inability to swim was examined by phase contrast light microscopy of a fresh liquid culture; (2) the inability of bacteria from a fresh culture to be agglutinated by the AS-Flal antiserum $(1: 100)$ was also verified by phase contrast light microscopy; (3) direct visualization of flagella by transmission electron microscopy of bacteria, negatively stained with $2 \%(\mathrm{w} / \mathrm{v})$ phosphotungstic acid $(\mathrm{pH} 7 \cdot 0)$.

Wheat root-binding assay for flagella. Five equally sized wheat roots, obtained as described by Michiels et al. (1991) were gently shaken at $30^{\circ} \mathrm{C}$ in $5 \mathrm{ml}$ MPCL (Lavigne, 1987) containing $10 \mu \mathrm{g}$ purified polar flagella $\mathrm{ml}^{-1}$ and the same concentration of purified lateral flagella. After $2 \mathrm{~h}$ incubation, roots were removed from the flagellar suspension, washed gentiy three times with water, and dried on absorbant paper. Root proteins were extracted in $2 \mathrm{ml}$ extraction buffer as described by De Mot \& Vanderleyden (1989). Two identical 8-25\% (w/v) SDS gradient polyacrylamide gels were run with a $2 \mu l$ sample from each extract together with a sample obtained from untreated roots as a control, using the Phast System (Pharmacia). After electrophoresis, both gels were blotted onto Imobilon PVDF membranes (Millipore) with the Phast System electroblotting equipment. The presence of Fla 1 and $\mathrm{Fla} 2$ on the blots was analysed by immunodetection with AS-Fla1 and AS-Fla2, respectively. A horseradish-peroxidase-conjugated goat anti-rabbit secondary antiserum was used in combination with 4chloro-1-naphthol as a substrate to develop the blots (Harlow \& Lane, 1988).

\section{Results}

The non-motile mutant $S p 7 p 900084$ lacks polar and lateral flagella

A. brasilense $\mathrm{Sp} 7 \mathrm{p} 90 \mathrm{D} 084$, constructed by exchange of a $13 \mathrm{~kb} \mathrm{BamHI}$ fragment from the $\mathrm{p} 90$ plasmid with a kanamycin resistance cartridge, is completely non-motile on solid and in liquid media, and is deficient in wheat root adsorption (Croes et al., 1991). Growth rates on different media and all other tested properties were as in the wild-type (Croes et al., 1991). We analysed the presence of flagella in this mutant by different methods. First, the presence of the polar flagellum was tested by adding AS-Fla1 antiserum to cells from a fresh broth culture or from a fresh plate. No agglutination could be observed by phase contrast light microscopy. AS-Fla2 was not used for this purpose because it was not sufficiently specific for the lateral flagella (see Methods). Second, the $100 \mathrm{kDa}$ (Fla1) and $45 \mathrm{kDa}$ (Fla2) flagellins from, respectively, the polar and the lateral flagella could not be detected by SDS-PAGE in a crude flagellar extract obtained from this mutant (data not shown). This extract further failed to produce opalescent bands upon $\mathrm{CsCl}$ gradient centrifugation. Finally, transmission electron microscopy of negatively stained mutant cells from a liquid culture and from a plate revealed the complete absence of flagella (Fig. 1).

\section{2-D PAGE protein analysis of mutant $S p 7$ p90D084}

Since $A$. brasilense adsorption to wheat roots involves a protease-sensitive component of the bacterial cell surface (Michiels et al., 1991), we compared the outer membrane proteins of wild-type strain $\mathrm{Sp} 7$ with those of the nonadsorbing mutant Sp7 p90D084 by 2-D PAGE (Fig. $2 a$ ). Both fingerprints were identical, and contained one major spot, corresponding to a $40 \mathrm{kDa}$ protein with low pI value, and five other minor spots. Flagella were not extracted by this membrane protein isolation procedure. A comparison of the 2-D PAGE fingerprints of total proteins from both strains revealed that the mutant lacked an acidic protein with an approximate molecular mass of $100 \mathrm{kDa}$ (circled spot in Fig. 2b). This protein was shown by immunoblot analysis to be the Fla1 flagellin (data not shown). The acidic protein (molecular mass, $28 \mathrm{kDa}$; marked by a square in Fig. $2 b$ ) appearing in the mutant was neomycin phosphotransferase (De Mot \& Vanderleyden, 1989), expressed from the Tn5derived kanamycin resistance cassette inserted in this mutant (Croes et al., 1991). Apart from these two proteins, there were no significant differences in the total protein patterns of both strains. The $45 \mathrm{kDa}$ Fla2 flagellin was not present in the extracts because these were from cells grown in liquid cultures. In conclusion, we could not detect any defect other than the absence of flagella in mutant $\mathrm{Sp} 7 \mathrm{p} 90 \mathrm{D} 084$. Next, we wanted to investigate whether this defect was responsible for the observed deficiency in adsorption of the mutant to wheat roots. 


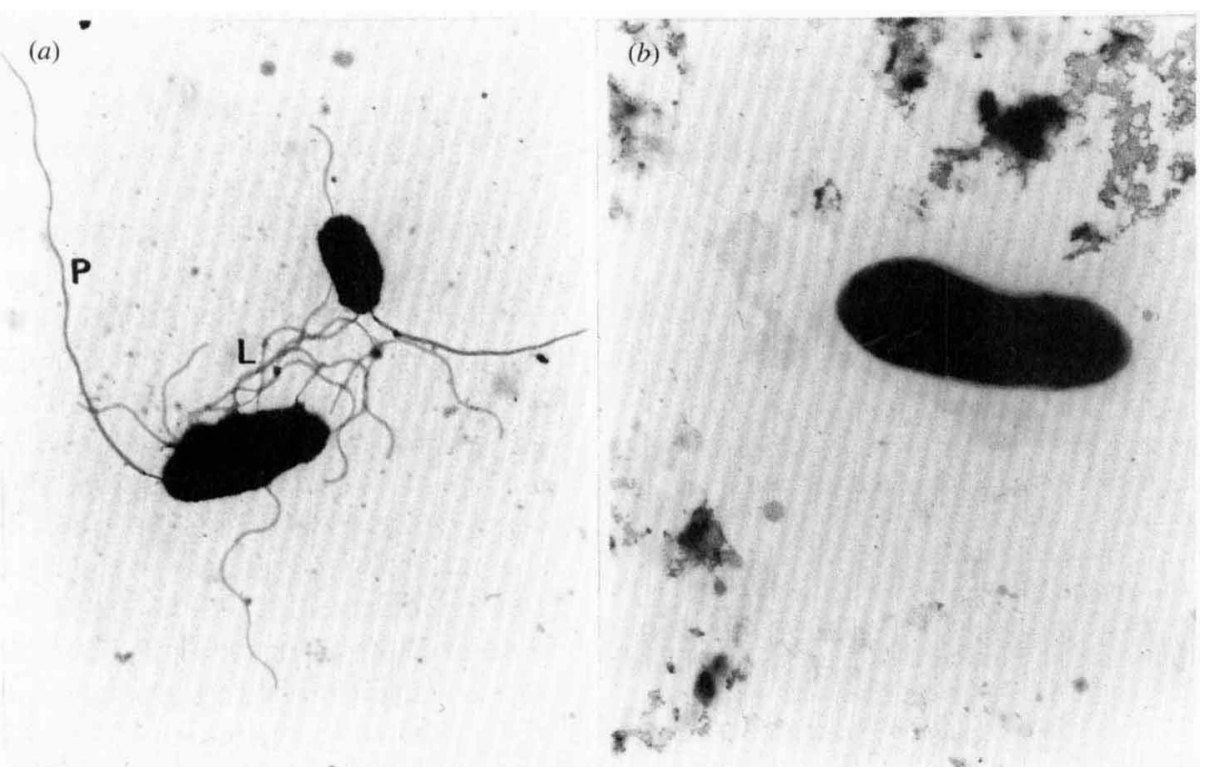

Fig. 1. Transmission electron micrograph of negatively-stained $A$. brasilense from a fresh plate. (a) Sp 7 , with single polar $(\mathbf{P})$ and several lateral (L) flagella. (b) Sp7 p90D084, without any flagella.

(a)

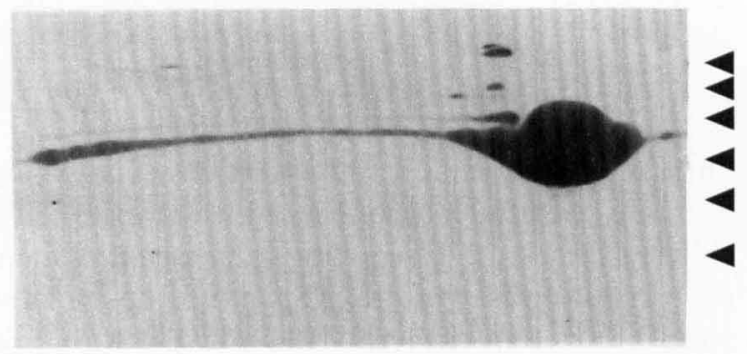

(b)

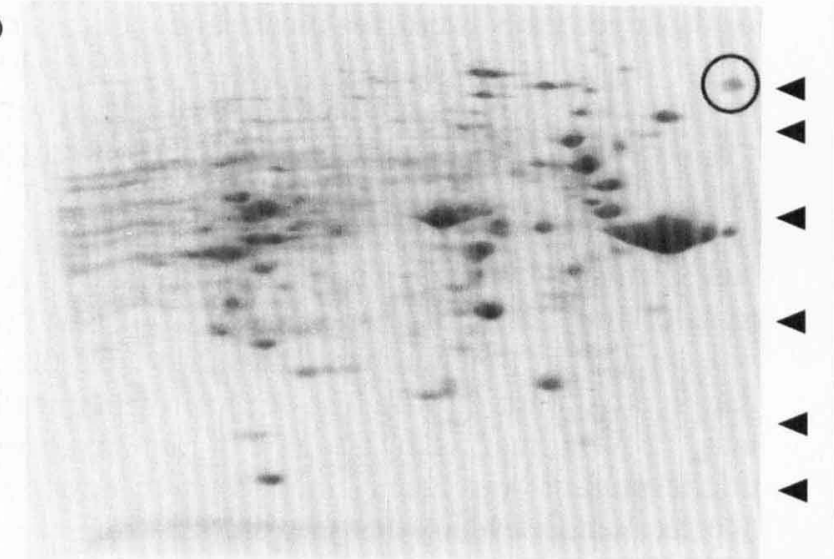

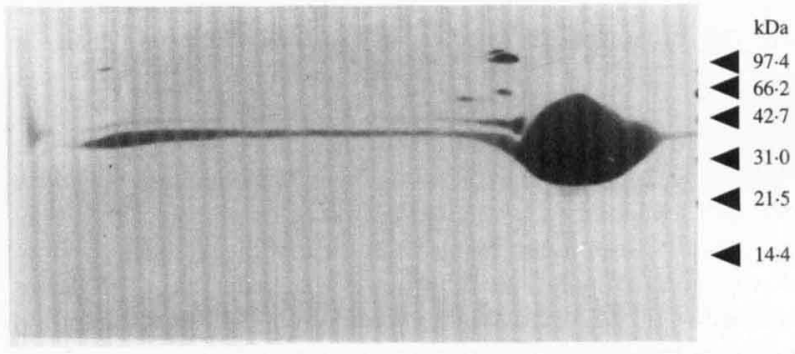

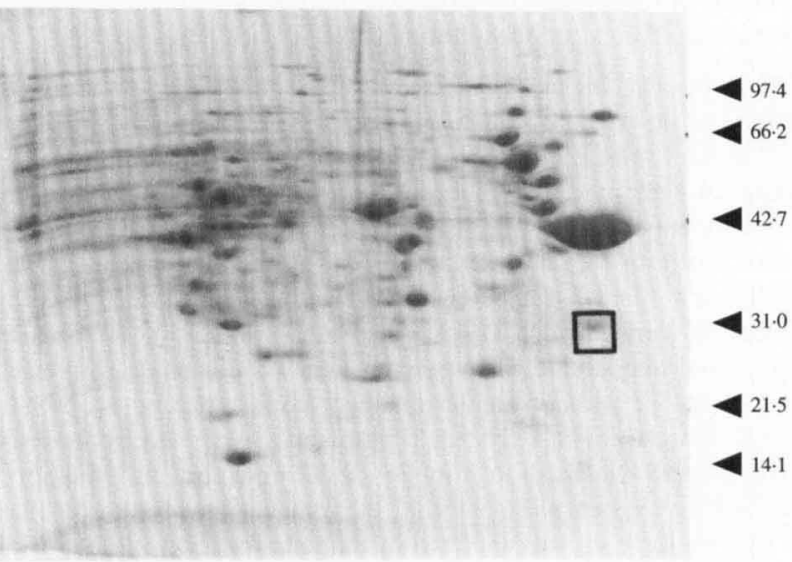

Fig. 2. 2-D PAGE protein analysis of $A$. brasilense $\mathrm{Sp} 7$ (left) and $\mathrm{Sp} 7 \mathrm{p} 90 \mathrm{D} 084$ (right) outer membrane proteins $(a)$ and total cellular proteins $(b)$. Outlined spots are discussed in the text. The arrowheads indicate the position of marker proteins. The $\sim 40 \mathrm{kDa}$ spot at the extreme right of the wild-type total protein gel is part of the major $40 \mathrm{kDa}$ protein spot. This artifact is caused by an air bubble during electrophoresis in the second dimension. The spot is not normally present (see 2-D electrophoretograms of strain Sp7 in De Mot \& Vanderleyden, 1989).

\section{Disintegration of flagella by heat or acid eliminates adsorption}

Bacterial flagellar filaments are supramolecular assemblies of thousands of flagellin subunits, that can be reversibly dissociated by heat or acid treatment (Joys, 1988). We subjected $A$. brasilense bacteria from a fresh liquid culture to a $5 \mathrm{~min}$ heat shock at different temperatures. After treatment, the bacteria were immediately centrifuged and resuspended in the original 
Table 2. Effect of heat and acid treatments on polar flagellum and wheat root adsorption of $A$. brasilense

Motility and agglutination with the antiserum against the polar filament protein Flal were evaluated by light microscopy.

\begin{tabular}{|c|c|c|c|}
\hline Treatment & Motility & $\begin{array}{l}\text { Agglutination } \\
\text { with AS-Flal }\end{array}$ & $\begin{array}{c}\text { Percentage } \\
\text { adsorption } \pm \mathrm{SD}\end{array}$ \\
\hline \multicolumn{4}{|l|}{ Heat } \\
\hline $5 \mathrm{~min}, 30^{\circ} \mathrm{C}$ & + & + & $2 \cdot 60 \pm 0.80$ \\
\hline $5 \min , 45^{\circ} \mathrm{C}$ & $t$ & + & $2.90 \pm 0.90$ \\
\hline $5 \mathrm{~min}, 55^{\circ} \mathrm{C}$ & \pm & \pm & $2.50 \pm 0.90$ \\
\hline $5 \min , 65^{\circ} \mathrm{C}$ & $\overline{-}$ & - & $0-44 \pm 0.26$ \\
\hline \multicolumn{4}{|l|}{ Acid $(\mathrm{pH})$} \\
\hline $3 \cdot 35$ & - & - & $0.64 \pm 0.45$ \\
\hline $4 \cdot 13$ & - & & $0 \cdot 24 \pm 0 \cdot 18$ \\
\hline $4 \cdot 51$ & - & \pm & $0.60 \pm 0.32$ \\
\hline $5 \cdot 25$ & + & + & $5.27 \pm 2.05$ \\
\hline $5 \cdot 65$ & + & + & $6 \cdot 73 \pm 1.40$ \\
\hline $6 \cdot 22$ & + & + & $6.46 \pm 2.85$ \\
\hline $6 \cdot 51$ & + & + & $6.51 \pm 2.33$ \\
\hline
\end{tabular}

volume of fresh medium to prevent reassociation of the flagella at room temperature. Removal of the polar flagellum was evaluated microscopically by inspecting motility and agglutination of the bacteria by AS-Fla1 antiserum. The effect of heat treatment on adsorption to wheat roots was tested separately using a radiolabelled bacterial culture. From the results, summarized in Table 2 , it can be concluded that motility and agglutination with AS-Flal are reduced at $55^{\circ} \mathrm{C}$ and are completely lost at $65^{\circ} \mathrm{C}$. Further, this apparent loss of the polar flagellum coincides with a sixfold reduction of wheat root adsorption capacity at $65^{\circ} \mathrm{C}$.

A similar experiment was set up for the low $\mathrm{pH}$ treatment. In this case, fresh bacteria were washed three times in $50 \mathrm{~mm}$-citrate/phosphate buffers at different $\mathrm{pH}$. After the final wash, they were resuspended in the $\mathrm{pH} \mathrm{7.0}$ buffer and evaluated for motility and agglutination with AS-Fla1, and for wheat root adsorption (radiolabelled bacteria). The results indicated a loss of the polar flagellum below pH 5.0 which is again concomitant with a loss of adsorption capacity (Table 2).

\section{Isolation of additional A. brasilense Fla ${ }^{-}$mutants by immunoscreening}

The initial screening for Fla1 ${ }^{-}$mutants by ELISA yielded 30 mutants out of a collection of approximately 3000 isolates. Further evaluation by light and electron microscopy reduced the number to 11 genuine Fla ${ }^{-}$ mutants lacking the polar flagellum. All the mutants had normal growth rates in complex and in defined media with different carbon and nitrogen sources, and normal colony and cell morphology. On the basis of the ELISA and microscopy results, we concluded that these mutants produce no extracellular Flal protein. It is possible that Flal is still produced intracellularly. In this location, however, it cannot contribute to wheat root adsorption of intact bacteria.

We performed a DNA hybridization using a Tn5-B30 specific probe on EcoRI- and HindIII-digested total DNAs of these mutants. This allowed us to distinguish three genetically different mutants, with Tn5-B30 insertions in different EcoRI and HindIII restriction fragments (Fig. 3). The size of the mutated EcoRI and HindIII fragments for each mutant can be calculated from the hybridization data. Since the smallest EcoRI fragment is $10 \mathrm{~kb}$ (without $\mathrm{Tn} 5$-B30, which measures $6 \mathrm{~kb}$ ), the positions of the three transposon insertions must be separated by at least $10 \mathrm{~kb}$. Hence, the insertions must define more than one gene, and most likely also more than a single gene cluster. Also, a comparison of the present data with the restriction map of the $A$. brasilense p90 plasmid, shows that none of the three new mutations map on this plasmid, and thus that the new mutants differ from the non-flagellate mutant $\mathrm{Sp} 7$ p90D084 described earlier (Croes et al., 1991).

\section{Adsorption to wheat roots of $A$. brasilense FlaI mutants}

Table 3 compares wheat root adsorption of the three newly isolated mutants, Sp7 p90D084, and the wild-type strain $\mathrm{Sp} 7$. In all four Fla $1^{-}$mutants, adsorption capacity was reduced to a background level, comparable to Escherichia coli adsorption capacity (Michiels et al., 1991). These results strongly suggest that the presence of the polar flagellum is required for wheat root adsorption. Since bacteria and roots were constantly agitated during the adsorption assay, the chances of contact with the root surface for flagellated and non-flagellated cells were the same. Thus, the role of motility was eliminated in our experiments, and our results show that the polar flagellum was involved in adsorption in a direct way. This was further confirmed in a direct binding assay between flagella and wheat roots.

\section{Binding of isolated polar flagella to wheat roots}

A mixture of $\mathrm{CsCl}$-purified polar and lateral $A$. brasilense flagella was incubated with wheat roots, under the same conditions as used in the bacterial adsorption assay. After three gentle washes, a protein extract of the roots was prepared, and the presence of Fla1 and Fla2 flagellins in this extract was analysed by SDS-PAGE and Western immunoblotting with flagellin-specific antisera. The immunoblot developed with AS-Fla1 showed no 


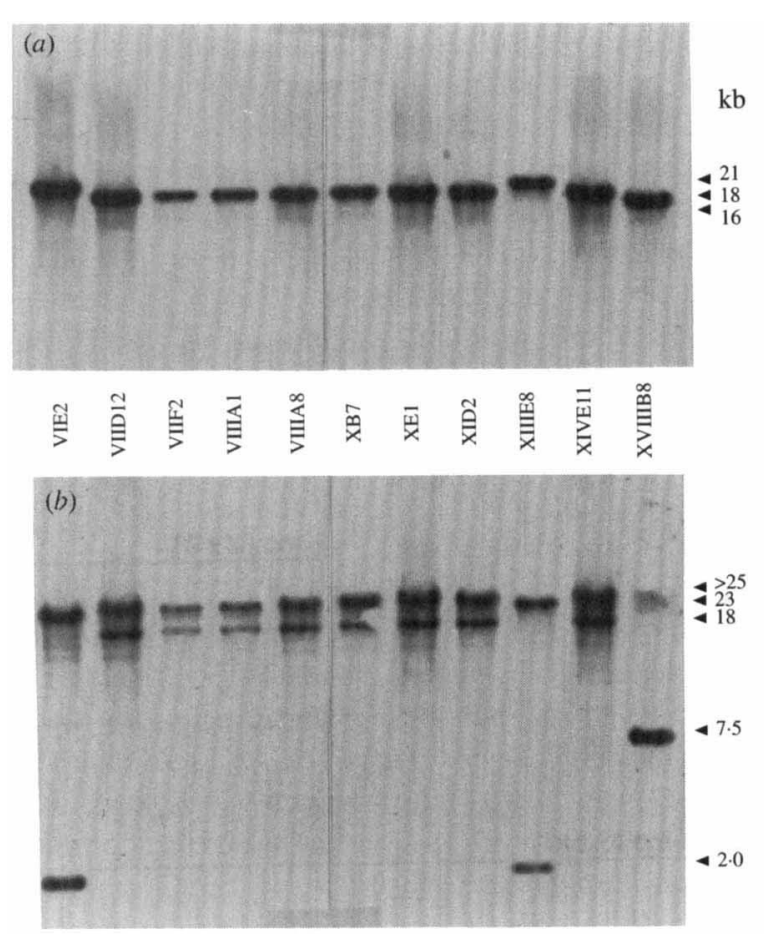

Fig. 3. Autoradiogram of hybridization on blots of restricted total DNAs from A. brasilense Tn5-B30 Fla1- mutants with a Tn5-B30specific probe. Estimated sizes of the fragments are indicated in $\mathrm{kb}$. (a) EcoRI-digested total DNA. Since EcoRI does not cleave Tn5-B30, single hybridization signals are found. (b) HindIII-digested total DNA. Since HindIII cleaves Tn5-B30 once, two hybridization signals are found. For mutant XVIIIB8, both bands are the same size.

Table 3. Adsorption to wheat roots of A. brasilense $S p 7$ and Flal $^{-}$mutants

\begin{tabular}{lc}
\hline \hline Strain & $\begin{array}{c}\text { Percentage } \\
\text { adsorption } \pm \text { SD }\end{array}$ \\
\hline Sp7 & $3 \cdot 15 \pm 0.42$ \\
Sp7 p90D084 & $0 \cdot 20 \pm 0 \cdot 14$ \\
Sp7 XB7 & $0 \cdot 21 \pm 0.03$ \\
Sp7 XIIIE8 & $0 \cdot 19 \pm 0.07$ \\
Sp7 XVIIIB8 & $0 \cdot 28 \pm 0 \cdot 13$ \\
\hline
\end{tabular}

signal for the control extracts from wheat roots that had not been incubated with flagella, and an intense band corresponding to Fla1 for the treated roots (Fig. 4 b). An identical immunoblot developed with AS-Fla2 showed a faint background signal for the untreated roots and a similar signal for the treated roots (Fig. $4 \mathrm{c}$ ).

As already pointed out in Methods, AS-Fla2 is less specific than AS-Fla1. It reacts rather poorly with Fla2, and strongly with two components in the flagellar preparation that do not stain with Coomassie blue. Therefore, the presence of only a background signal on the immunoblots of proteins from treated roots de- (a)

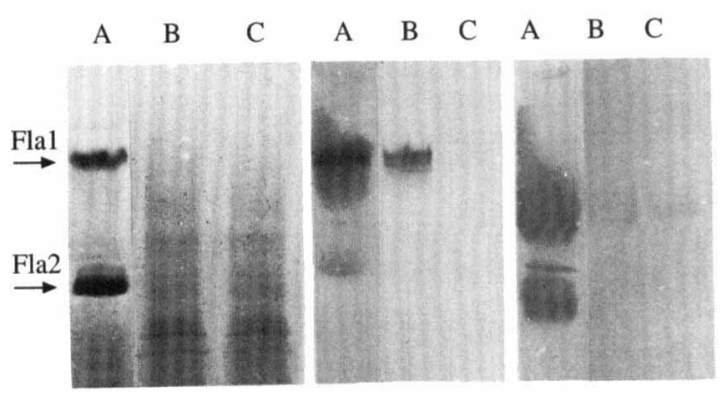

Fig. 4. Immunodetection of Fla1 and Fla2 on Western blots of protein extracts of wheat roots incubated with a mixture of Flal and Fla2. (a) Coomassie blue-stained polyacrylamide gels; $(b)$ Western blot developed with AS-Fla1; $(c)$ Western blot developed with AS-Fla2. Lanes: A, Fla1/Fla2 protein mixture; B, protein extract of wheat roots incubated with the Fla1/Fla2 mixture; $C$, protein extract from unincubated wheat roots.

veloped with AS-Fla2, demonstrates that the roots have been sufficiently washed to remove any non-binding material. Thus, it can be concluded that, under the conditions of this experiment, the polar flagella bind to wheat roots. It also seems that Fla2 did not bind to the same degree as Fla1. However, small amounts of Fla2 may have been missed due to the lower sensitivity of Fla2 detection.

Wheat root adsorption is not inhibited by anti-Flal antiserum or by excess polar flagella

If the polar flagellum is responsible for adsorption to wheat roots, one would expect adsorption to be inhibited by excess polar flagella and eventually by AS-Fla1. We observed only a slight and statistically non-significant decrease of adsorption in the presence of high concentrations (1:10 dilution) of AS-Flal (data not shown), suggesting that the antibodies do not bind to the domains of Fla1 involved in wheat root binding. Further, the addition of excess polar flagella $\left(200 \mu \mathrm{g} \mathrm{ml}^{-1}\right)$ did not affect adsorption. This result seems to be in conflict with the root-adhesive properties of the $A$. brasilense flagella, but can be explained by taking into account the particular properties of bacterial flagella (see Discussion).

\section{Discussion}

Earlier studies have shown that the rapid and reversible adsorption of $A$. brasilense to wheat roots depends on a bacterial protease-sensitive cell surface component (Michiels et al., 1991). In the present work, we have identified this wheat root adhesin as a component of the 
bacterial polar flagellar filament. Three independent pieces of evidence are presented.

First, we used heat and acid treatments to dissociate the flagellar filaments of $A$. brasilense cells. Loss of the filaments was monitored by the loss of swimming motility, and by the inability to be agglutinated by ASFla1, a polyclonal antiserum against the polar flagella. It was found that the same conditions that dissociated the polar filament also eliminated the ability to adsorb to wheat roots. Evidently, since physico-chemical methods like heat and acid treatment are likely to affect several outer membrane constituents, these results do not rule out the possible involvement of components other than the flagella in adsorption. The involvement of the lateral flagella can be excluded in our adsorption assay, since we always used bacteria grown in liquid growth medium, and these do not have lateral flagella (Tarrand et al., 1978). Heat treatment was also shown to eliminate adsorption of $A$. brasilense to suspended plant cells (Eyers et al., 1988).

Second, in order to confirm the possible involvement of the polar flagellum in wheat root adsorption, we tested four different mutants lacking the polar flagellar filament protein Fla1. One of these is a plasmid deletion mutant, previously described as adsorption deficient and nonmotile (Croes et al., 1991), and which is shown here to be $\mathrm{Flal}^{-}$. The three others were isolated in this study by immunoscreening with AS-Fla 1, and they were all shown to be adsorption deficient. Since the adsorption experiments were carried out under well-agitated conditions, the role of bacterial motility can be discounted, and the adsorption deficiency of the non-flagellated mutants probably reflects the loss of a bacterial root adhesin. The lack of flagella is not due to a severe pleiotropic surface defect, since all the mutants have normal growth rates on different media, and normal colony and cell morphology. Because these four mutants carry mutations that are not closely linked, it is very unlikely that they would all share a common defect in one of the outer membrane proteins, in addition to the absence of the polar flagellum. Therefore, these results provide strong indirect evidence that the polar flagellum functions as a wheat root adhesin.

Finally, we showed that, under the same conditions as used to measure adsorption of whole bacteria, Flal bound effectively to wheat roots. This confirmed our assumption that the adsorption deficiency of the Fla ${ }^{-}$ mutants is not caused by the lack of motility but by the lack of the flagellar adhesin.

At first glance, the finding that wheat root adsorption is not reduced by the addition of excess polar flagella seems contradictory to the proposed adhesin function of this flagellum. However, bacterial flagella possess the particular capacity to disintegrate into monomers and to reassemble, and there was no control on this process in our experimental set-up. Possibly, the free flagellar fragments adsorbed on the roots reassemble with flagella attached to the bacteria.

The best studied example of bacterial adhesion is probably the colonization of human or animal host cells by pathogenic Escherichia coli. The adhesins in this bacterium are minor constituents of heteropolymeric fibres pointing outward from the cells, called pili (Lindberg et al., 1986). Usually, the adhesins are located at the tip of the pili, a construction that warrants the optimal access to the receptor molecules on the host cell surface (Lindberg et al., 1987; Kuehn et al., 1992). A similar attachment strategy may be very widespread among Gram-negative bacteria, since the involvement of pili or fimbriae has been shown in many diverse interactions, such as the attachment of Serratia marcescens to the urinary tract (Mizunoe et al., 1991), or the adhesion of the periodontal pathogen Porphyromonas gingivalis to Actinomyces viscosus (Goulbourne \& Ellen, 1991). Fimbriae have also been implicated in attachment of bacteria to plants, as in nitrogen-fixing Klebsiella spp. (Korhonen et al., 1983) and Enterobacter spp. (Haahtela et al., 1985) associating with grass roots, in Bradyrhizobium japonicum attaching to soybean roots (Vesper \& Bauer, 1986), or in Pseudomonas syringae pv. phaseolica, attaching to bean leaf stomata (Romanschuk \& Bamford, 1986).

Bacterial flagella, in contrast to pili or fimbriae, are cell appendages that can rotate, and that serve primarily for locomotion. In terms of access to the target surface, one would predict that the location of a bacterial adhesin on the flagella or on the pili or fimbriae offers the same advantage. However, bacterial flagella have rarely been implicated in attachment, and often their only role is to increase the number of encounters between the bacterium and the surface by providing motility to the bacterium (Stanley, 1983; De Weger et al., 1987; Piette \& Idziak, 1991). In these cases, the higher adsorption capacity of flagellated cells was lost when the experiment was conducted with vigorous agitation (Stanley, 1983; Lillard, 1985). Therefore, surface-adhesive properties should not be ascribed to flagella solely on the basis of a reduced adsorption of deflagellated bacteria or nonflagellate bacterial mutants, when no well agitated conditions were used. This was the case for instance in adhesion studies of Pseudomonas fluorescens (De Flaun et al., 1990), and of Vibrio parahaemolyticus (Belas \& Colwell, 1982). The polar flagella of $P$. fluorescens were implicated in the adsorption of this bacterium to a soil amoeba on the basis of light and electron microscopical observations (Preston \& King, 1984). However, nonflagellated bacteria were not used in this study. To the best of our knowledge, A. brasilense represents the first 
case of a flagellar adhesin shown to be involved in a bacterium-plant interaction (Smit \& Stacey, 1990).

K.M. is a senior research assistant of the Nationaal Fonds voor Wetenschappelijk Onderzoek (NFWO), and C.L.C. had a fellowship from the Instituut voor Wetenschappelijk Onderzoek in de Nijverheid en de Landbouw (IWONL). This work was supported by grants from the Fonds voor Geneeskundig Wetenschappelijk Onderzoek (FGWO 3.0093.89), and from the K.U. Leuven Onderzoeksfonds (OT/88/20).

We thank the electron microscopy laboratory of the Centre for Human Genetics at the K.U. Leuven for the use of their equipment, and J. Vloeberghs for photography.

\section{References}

Bashan, Y. \& LeVanONy, H. (1988). Active attachment of Azospirillum brasilense $\mathrm{Cd}$ to quartz sand and to light-textured soil by protein bridging. Journal of General Microbiology 134, 2269-2279.

Belas, R. M. \& Colwell, R. R. (1982). Adsorption kinetics of laterally and polarly flagellated Vibrio. Journal of Bacteriology 151, $1568-1580$.

Croes, C., Van Bastelaere, E., Declerco, E., Eyers, M., VanderLEYDEN, J. \& MICHIELS, K. (1991). Identification and mapping of loci involved in motility, adsorption to wheat roots, colony morphology, and growth in minimal medium on the Azospirillum brasilense Sp7 90 MDa plasmid. Plasmid 26, 83-93.

DAvison, J. (1988). Review: plant beneficial bacteria. Biotechnology 6, 282- 286.

De Flaun, M. F., Tanzer, A. S., Mcateer, A. L., Marshall, B. \& Levy, S. B. (1990). Development of an adhesion assay and characterization of an adhesion-deficient mutant of Pseudomonas fiuorescens. Applied and Environmental Microbiology 56, 112-119.

DE Mot, R. \& VANDerleyden, J. (1989). Application of twodimensional protein analysis for strain fingerprinting and mutant analysis of Azospirillum species. Canadian Journal of Microbiology $35,960-967$.

De Pamphilis, M. L. \& Adler, J. (1971). Purification of intact flagella from Escherichia coli and Bacillus subtilis. Journal of Bacteriology $105,376-383$.

De Weger, L. A., Van der Vlugt, C. I. M., WiJfjes, A. H. M., BAKKeR, P. A. H. M., SCHIPPERS, B. \& LUGTENBERG, B. (1987). Flagella of plant-growth-stimulating Pseudomonas fuorescens strain are required for colonization of potato roots. Journal of Bacteriology 169, 2769-2773.

Eyers, M., Vanderleyden, J. \& Van Gool, A. (1988). Attachment of Azospirillum to isolated plant cells. FEMS Microbiology Letters 49, 435-439.

GaFNY, R., OKON, Y. \& KaPULNIK, Y. (1986). Adsorption of Azospirillum brasilense to corn roots. Soil Biology and Biochemistry $18,69-75$.

Goulbolrne, P. A. \& Ellen, R. P. (1991). Evidence that Porphyromonas (Bacteroides) gingivalis fimbriae function in adhesion to Actinomyces viscosus. Joumal of Bacteriology 173, 5266-5274.

HaAhtela, K., TarkKa, E. \& Korhonen, T. K. (1985). Type 1 fimbriae-mediated adhesion of enteric bacteria to grass roots. Applied and Environmental Microbiology 49, 1182-1185.

Harlow, E. \& Lane, D. (1988). Antibodies. A Laboratory Manual. Cold Spring Harbor, NY: Cold Spring Harbor Laboratory.

Hurlber T, R. E. \& Gross, D. C. (1983). Isolation and partial characterization of the cell wall of Pseudomonas syringae pv. syringae HS191: comparison of outer membrane proteins of HS191 with those of two plasmidless derivatives. Journal of General Microbiology 129, 2241-2250.

Jain, D. K. \& Patriquin, D. G. (1984). Root hair deformation, bacterial attachment and plant growth in wheat-Azospirillum associations. Applied and Environmental Microbiology 48, 1208-1213.

JoYs, T. M. (1988). The flagellar filament protein. Canadian Journal of Microbiology 34, 452-458.
Korhonen, T. K., TaRkKa, E., Ranta, E. \& HaAhtela, K. (1983). Type 3 fimbriate of Klebsiella sp.: molecular characterization and role in bacterial adhesion to plant roots. Journal of Bacteriology 155, 860-865.

Kuehn, M. J., Heuser, J., Normark, S. \& Hultgren, S. J. (1992). P pili in uropathogenic $E$. coli are composite fibres with distinct fibrillar adhesive tips. Nature, London 356, 252-255.

LAvigne, C. (1987). Contribution à l'étude du système racinaire du bananier. Mise au point de rhizotrons et premiers résultats. Fruits $\mathbf{4 2}$, 265-271.

LILLARD, H. S. (1985). Bacterial cell characteristics and conditions influencing their adhesion to poultry skin. Journal of Food Proteins 48, 803-807.

LindberG, F., Lund, B. \& Normark, S. (1986). Gene products specifying adhesion of uropathogenic Escherichia coli are minor components of pili. Proceedings of the National Academy of Sciences of the United States of America 83, 1891-1895.

LindberG, F., Lund, B., Johansson, L. \& Normark, S. (1987). Localization of the receptor-binding protein adhesin at the tip of the bacterial pilus. Nature, London 328, 84-87.

LugtenberG, B. J. J., DE Weger, L. A. \& BennetT, J. W. (1991) Microbial stimulation of plant growth and protection from disease. Current Opinion in Biotechnology 2, 457-464.

Madi, L. \& Henis, Y. (1989). Aggregation in Azospirillum brasilense $\mathrm{Cd}$ : conditions and factors involved in cell-to-cell adhesion. Plant and Soil 115, 89-98.

Michiels, K., Vanderleyden, J. \& Van Gool, A. (1989). Azospirillum-plant root associations: a review. Biology and Fertility of Soils 8, 356-368.

Michiels, K., Verreth, C. \& VANderleyden, J. (1990). Azospirillum lipoferum and Azospirillum brasilense surface polysaccharide mutants that are affected in flocculation. Journal of Applied Bacteriology 69, $705-711$.

Michiels, K., Croes, C. \& Vanderleyden, J. (1991). Two different modes of attachment of Azospirillum brasilense $\mathrm{Sp} 7$ to wheat roots. Journal of General Microbiology 137, 2241-2246.

Mizunoe, Y., Matsumoto, T., Amako, K., Sekiguchi, M. \& Kumazawa, J. (1991). Identification and nucleotide sequence of the gene determining the adhesion capacity of Serratia marcescens. Joumal of Bacteriology 173, 3257-3260.

Murty, M. G. \& LadHa, J. K. (1987). Differential colonization of Azospirillum lipoferum on roots of two varieties of rice (Oryza sativa L.). Biology and Fertility of Soils 4, 3-7.

Patriquin, D. G. (1981). New developments in grass-bacteria associations. In Advances in Agricultural Microbiology, pp. 139-190. Edited by N. S. Subba-Rao. New Dehli, India: Oxford \& IBH Publishing.

Patriquin, D. G., Döbereiner, J. \& JanN, D. K. (1983). Sites and processes of associations between diazotrophs and grasses. Canadian Joumal of Microbiology 29, 900-915.

PIETTE, J.-P. G. \& IDZIAK, E. S. (1991). Role of flagella in adhesion of Pseudomonas fluorescens to tendon slices. Applied and Environmental Microbiology 57, 1635-1639.

Preston, T. M. \& King, C. A. (1984). Binding sites for bacterial flagella at the surface of the soil amoeba Acanthamoeba. Journal of General Microbiology 130, 1449-1458.

RomanschuK, M. \& BamFord, D. H. (1986). The causal agent of halo blight in bean, Pseudomonas syringae pv. phaseolica, attaches to stomata via its pili. Microbial Pathogenesis 1, 139-148.

SambrooK, J., Fritsch, E. F. \& Maniatis, T. (1989). Molecular Cloning. A Laboratory Manual, 2nd edn. Cold Spring Harbor, NY: Cold Spring Harbor Laboratory.

Simon, R., Quandt, J. \& KLIPP, W. (1989). New derivatives of transposon Tn 5 suitable for mobilization of replicons, generation of operon fusions and induction of genes in Gram-negative bacteria. Gene 80, 161-169.

SMIT, G. \& STACEY, G. (1990). Adhesion of bacteria to plant cells: role of specific interactions versus hydrophobicity. In Microbial Cell Encelope Hydrophobicity, pp. 179-210. Edited by R. J. Doyle \& M Rosenberg. Washington, DC: American Society for Microbiology. STANLEY, P. M. (1983). Factors affecting the irreversible attachment of Pseudomonas aeruginosa to stainless steel. Canadian Journal of Microbiology 29, 1493-1499. 
Tarrand, J. J., KRIEG, N. \& Döbereiner, J. (1978). A taxonomic study of the Spirillum lipoferum group, with the description of a new genus, Azospirillum gen. nov. and two new species, Azospirillum lipoferum (Beyerinck) comb. nov. and Azospirillum brasilense sp. nov. Canadian Journal of Microbiology 24, $968-980$.

Umali-Garcia, M., Hubbell, D. H., Gaskins, M. H. \& Dazzo, F. B. (1980). Association of Azospirillum with grass roots. Applied and Environmental Microbiology 39, 219-226.
Vanstockem, M., Michiels, K., Vanderleyden, J. \& Van Gool, A. (1987). Transposon mutagenesis of Azospirillum brasilense and Azospirillum lipoferum: physical analysis of Tn5 and Tn5-Mob insertion mutants. Applied and Environmental Microbiology 53, 410-425.

Vesper, S. J. \& Bauer, W. D. (1986). Role of pili (fimbriae) in attachment of Bradyrhizobium japonicum to soybean roots. Applied and Environmental Microbiology 52, 134-141. 